\title{
NEW RADIOCARBON DATES FOR THE GRENADINE ISLANDS (WEST INDIES)
}

\author{
Scott M Fitzpatrick \\ Department of Sociology and Anthropology, North Carolina State University, Raleigh, North Carolina, USA. Corresponding \\ author. Email: scott_fitzpatrick@ncsu.edu. \\ Christina M Giovas \\ Department of Anthropology, University of Washington, Seattle, Washington, USA.
}

\begin{abstract}
Intensified archaeological research in the Caribbean over the past 2 decades has provided a wealth of new information on how and when these islands were settled prehistorically. However, there has been a paucity of research on islands in the southern Lesser Antilles, which would allow for more rigorous testing of migration models and various settlement pattern hypotheses. To address some of these chronological and geographical gaps, we present a corpus of 41 radiocarbon dates from several sites in the Grenadine Island chain. Results to date support a relatively late Ceramic Age settlement of these smaller islands (about AD 400) compared to other nearby, larger islands in the southern Lesser Antilles (about AD 200 ) as well as the Caribbean as a whole (about 400/500 BC). Intriguing questions also remain as to an apparent, but as yet inadequately tested, pattern where earlier colonization dates are correlated with larger island size.
\end{abstract}

\section{INTRODUCTION}

Over the last few decades, archaeological research in the Caribbean has steadily intensified, generating a tremendous amount of new data. This includes increased attention by archaeologists to radiocarbon dating that has helped refine chronologies of human colonization, settlement, and subsequent cultural changes that occurred over time. Critical appraisal of whether all dates meet analytic standards for use in the construction of chronologies has generally been lacking in the region though (see Fitzpatrick 2006). Many recent papers have illustrated why this issue is important, with closer scrutiny of dates leading to, for example, new insights about the distribution of prehistoric settlements (Cooper 2010) and how artifact typologies in the Caribbean are structured (Rodríguez Ramos 2010).

A major geographical gap in the investigation of Pre-Columbian societies in the Caribbean, and henceforth the development of ${ }^{14} \mathrm{C}$ chronologies that would help contextualize settlement patterns in the region, is in the southern Lesser Antilles south of Guadeloupe where research has been generally sparse and virtually nonexistent on some islands since the 1960s (Bullen and Bullen 1972). Although research initiatives on the larger islands of Barbados (Drewett 1991, 2000), St. Lucia (Hofman and Hoogland 2009), and St. Vincent (Callaghan 2007), for example, have provided new clues as to when this part of the Caribbean was settled, the Grenadines in particular remain somewhat of an enigma. As a testament to the deficiency in research, until 2004 only 3 sites had been excavated (albeit sparsely) and only $4{ }^{14} \mathrm{C}$ dates from archaeological sites existed for all of the Grenadines despite over 50 sites having been identified (see Bullen and Bullen 1972).

To address this issue, we present a list of all known ${ }^{14} \mathrm{C}$ dates from archaeological contexts in the Grenadines. Of the 41 dates now available, 37 are new and derive from research led by Fitzpatrick and colleagues, with 15 of those previously unreported. The compilation of this extensive suite of dates provides an important framework for investigating a host of important issues in Caribbean archaeology, ranging from colonization events, migration strategies, and settlement patterns within and between islands in the southern Lesser Antilles, as well as questions related to apparent site and/ or island abandonment prior to European contact in the late 1400s.

\section{RESEARCH BACKGROUND}

The Grenadines are a chain of 6 major islands-Bequia, Mustique, Mayreau, Canouan, Union, and Carriacou, and numerous smaller ones with a total land mass of $80 \mathrm{~km}^{2}$ - that stretch for $60 \mathrm{~km}$ 
between Grenada and St. Vincent in the southern Caribbean (Figure 1). The Grenadines lie on the southern Lesser Antilles arc platform (SLAAP) between the 2 most active volcanoes of the Lesser Antilles magmatic arc - the subaerial St. Soufriere Volcano on St. Vincent (Heath et al. 1998a) and the submarine volcano Kick'em Jenny between Grenada and Carriacou (Heath et al. 1998b). The arc is a product of Miocene uplift (23-16 Ma) and characterized by Eocene to Pliocene extrusive to intrusive igneous rocks along with sedimentary rocks such as limestone, marl, and chert, and epiclastic arc-derived volcaniclastic units composed of mudstone, sandstone, and conglomerate (Speed et al. 1993; Donovan et al. 2003; Jackson et al. 2008). The islands are comprised of a variety of volcanic and sedimentary rocks. Recent volcanism is limited primarily to Kick-Em-Jenny (Speed et al. 1993; Devine and Sigurdsson 1995; Lindsay et al. 2005) though the smaller islands just north of Grenada, including Isle de Caille, are considered to be volcanically youthful (Sigurdsson and Shepherd 1974).

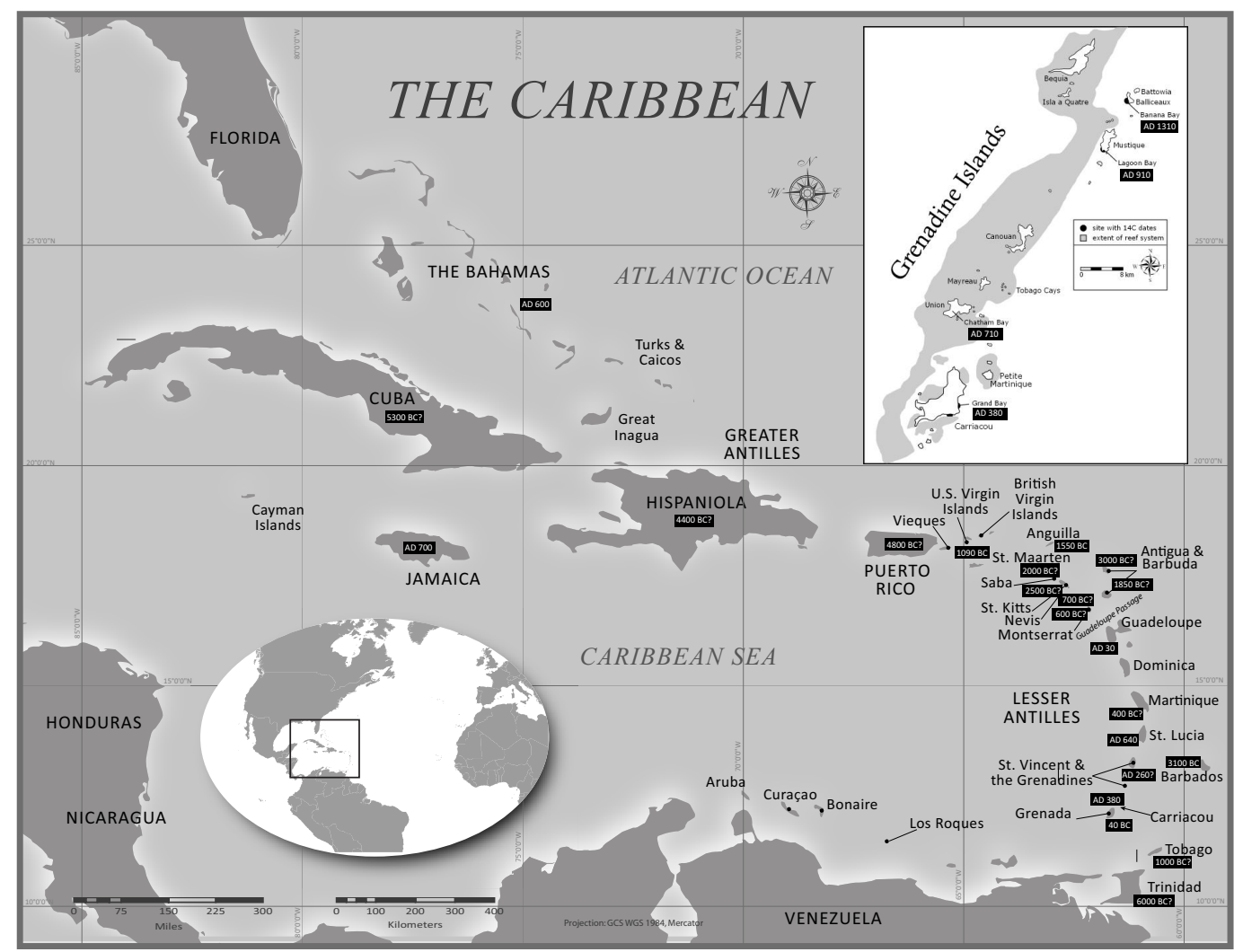

Figure 1 Map of the Caribbean with inset of the Grenadines showing the earliest acceptable ${ }^{14} \mathrm{C}$ dates $(2 \sigma)$ found on each island in the Antilles (data from Fitzpatrick 2006; Wilson 2007; Cooper 2010; Rodríguez Ramos 2010).

In comparison to the higher and much larger islands of Grenada and St. Vincent, the Grenadines exhibit relatively low relief. Maximum elevations generally fall under 200-300 m, which limits orographic rainfall and promotes arid conditions, especially during the pronounced winter dry season, despite moist prevailing winds from the northeast. Prehistorically, the hilly terrain of these islands would have been covered in xeric scrub habitat, particularly along coastal areas. Some islands such as Carriacou lack permanent streams or rivers, although well-springs collect in natural basins along with rainwater during the wet season (Bullen and Bullen 1972; Sutty 1991). Freshwater could also be extracted by digging wells and lining them with ceramic potstacks, which was a technique used 
on several islands in the southern Caribbean, including Carriacou, Mustique, and Barbados (Drewett 2007:49-63).

Soil quality is relatively low and terrestrial environments lack large, endemic, nonvolant animals, particularly mammals, which are represented on the islands prehistorically by only bats and possibly rice rats (Oryzomyini). Perhaps for these reasons the archaeological record for the region indicates the introduction of several South American taxa, including the agouti (Dasyprocta sp.), the opossum (Dideplphis sp.), and possibly the green iguana (Iguana iguana) for dietary consumption (Newsom and Wing 2004; Stahl 2009; Giovas et al., forthcoming). The zooarchaeological record also suggests heavy exploitation of marine resources, particularly finfish and gastropod mollusks (LeFebvre 2007; Fitzpatrick et al. 2009; Giovas 2009). In contrast to the larger islands that bound them to the north and south, the Grenadines have relatively extensive reef development with large bank barrier reef complexes on the windward side of some islands, especially off the eastern coasts of Petit Martinique, Carriacou, and the Tobago Cays (Tupper et al., http://www.reefbase.org).

Archaeologically, the Grenadines have received little attention until recently. Although Jesse Fewkes (1914) ventured through the islands collecting representative samples of artifacts for the Smithsonian Institution - supplemented later with more extensive surveys by I A Earle Kirby (1969) through the St. Vincent Archaeological and Historical Society—Ripley and Adelaide Bullen (1972) were the first to initiate a more concerted research program to record Pre-Columbian settlements in the region. Through these efforts, a number of important sites were reported in the Grenadines, though only Sabazan on Carriacou and Chatham Bay on Union were excavated to any degree, which was later supplemented by Sutty's (1975) work at Miss Pierre on Union. This early research indicated a comparatively late occupation of these islands during the Ceramic Age, which throughout the Antilles spans a period of about $500 \mathrm{BC}-\mathrm{AD} 1400$. Bullen and Bullen's temporal assignment of sites was based largely on ceramic typologies. However, they did obtain a single ${ }^{14} \mathrm{C}$ date from the excavation of a foot-thick "slice" of Sabazan's coastal profile $(940 \pm 100 \mathrm{BP})$ as well as $1{ }^{14} \mathrm{C}$ date at Chatham Bay (1470 $\pm 110 \mathrm{BP})$ that in general confirmed their estimates (Bullen and Bullen 1972: 14-7) (see Table 1).

In 2003, Fitzpatrick and colleagues Quetta Kaye and Michiel Kappers initiated a research project on Carriacou, the largest and southernmost island in the Grenadines. Intensive survey found or rerecorded at least a dozen sites (Fitzpatrick et al. 2006, 2009) with artifactual assemblages that were typical of Ceramic Age deposits. Later excavation at the 2 largest of these sites-Grand Bay by Fitzpatrick and colleagues and Sabazan by Giovas as part of her PhD research — over several field seasons $(2004-5,2007-8,2011)$, demonstrate that both sites contain a wide array of archaeological remains and features indicative of long-term habitation that span the terminal part of the Saladoid period (about AD 1-500/600) on through the Troumassan Troumassoid (about AD 600-1000) and Suazan Troumassoid (about AD 1000-1400) subseries of ceramic styles (see Fitzpatrick et al. 2004, 2009; also Petersen et al. 2004 for description of ceramic typologies). In addition to Carriacou, research has also begun to expand to other islands in the north (Fitzpatrick et al. 2007) and includes preliminary subsurface testing by Fitzpatrick and Kappers in May 2010 at 2 Chatham Bay sites (a northern and southern one, referred to by Bullen and Bullen [1972] as "Chatham Midden" and "Chatham Pasture," respectively) and Miss Pierre on Union Island, a previously unrecorded site on Mustique known as Lagoon Bay, and ${ }^{14} \mathrm{C}$ dating of the eroded coastal profile at Banana Bay on Baliceaux. New archaeological data from these sites, along with those on Carriacou, have supplemented earlier work and built a strong foundation for continuing more intensive investigations of the Grenadines in the near future. More importantly, it has allowed us to develop a better chronology of human settlement in this smaller island chain as we discuss below. 
Table 1 Radiocarbon dates from the Grenadine Islands (calibrated with CALIB 6.0.1 using the IntCal09 and Marine 09 calibration curves). Human bone calibrated as 50\% marine $/ 50 \%$ terrestrial to reflect a mixed diet.

\begin{tabular}{|c|c|c|c|c|c|c|c|c|c|}
\hline Site & Lab nr & Type & Species & Unit & Layer & $\begin{array}{l}\text { Depth } \\
\text { (cmbs) }\end{array}$ & $\begin{array}{l}{ }^{13} \mathrm{C} /{ }^{12} \mathrm{C} \\
\text { ratio }\end{array}$ & $\begin{array}{l}\text { Measured } \\
{ }^{14} \mathrm{C} \text { age }\end{array}$ & $\begin{array}{l}\text { cal AD } \\
(2 \sigma)\end{array}$ \\
\hline \multicolumn{10}{|l|}{ Carriacou } \\
\hline Grand Bay & AA-62278 & shell & C. pica & 447 & XV & 145 & 2.53 & $1917 \pm 37$ & $390-590$ \\
\hline Grand Bay & AA-62279 & charcoal & - & 447 & VI & 110 & -25.13 & $1243 \pm 36$ & $680-880$ \\
\hline Grand Bay & AA-62280 & shell & Venus sp. & 447 & VI & 127 & 3.39 & $1789 \pm 38$ & $530-690$ \\
\hline Grand Bay & AA-62280 & shell & Venus sp. & 447 & VI & 127 & 3.36 & $1822 \pm 41$ & $470-670$ \\
\hline Grand Bay & AA-62281 & charcoal & - & 447 & VI & 93 & -23.96 & $1339 \pm 36$ & $640-770$ \\
\hline Grand Bay & AA-62282 & charcoal & - & F016 & - & - & -25.97 & $1227 \pm 36$ & $690-890$ \\
\hline Grand Bay & AA-62283 & bone & $\begin{array}{l}\text { human } \\
\text { (child- } \\
\text { rt. fibula) }\end{array}$ & F006 & - & - & -14.21 & $1062 \pm 44$ & $1050-1250$ \\
\hline Grand Bay & $\begin{array}{l}\text { Beta- } \\
206685\end{array}$ & shell & $\begin{array}{l}\text { E. gigas } \\
\text { (juvenile) }\end{array}$ & N. profile & - & 108 & 2.1 & $1870 \pm 70$ & $380-670$ \\
\hline Grand Bay & $\begin{array}{l}\text { Beta- } \\
233647\end{array}$ & shell & C. pica & 415 & $\mathrm{~V}$ & - & 1.8 & $870 \pm 40$ & $1020-1200$ \\
\hline $\begin{array}{l}\text { Harvey } \\
\text { Vale }\end{array}$ & AA-62284 & bone & $\begin{array}{l}\text { human } \\
\text { (rt. ulna) }\end{array}$ & - & - & - & -12.55 & $1027 \pm 46$ & $1060-1280$ \\
\hline Sabazan & RL-29 & charcoal & - & midden & - & $\sim 60-80$ & - & $940 \pm 100$ & $900-1270$ \\
\hline Sabazan & GX-30423 & shell & C. pica & profile & VI & 160 & 2.4 & $1400 \pm 60$ & $870-1160$ \\
\hline Sabazan & GX-30424 & shell & E. gigas & profile & $\mathrm{X}$ & 200 & 0.2 & $1570 \pm 60$ & $690-970$ \\
\hline Sabazan & GX-30425 & shell & C. pica & profile & XI & 230 & 2.5 & $1460 \pm 60$ & $790-1060$ \\
\hline Sabazan & OS-41358 & charcoal & - & profile & $\mathrm{X}$ & 215 & -23.94 & $1030 \pm 30$ & $900-1120$ \\
\hline Sabazan & AA-67529 & charcoal & - & profile & XI & $53-108$ & -25.6 & $988 \pm 42$ & $980-1160$ \\
\hline Sabazan & AA-67530 & charcoal & - & profile & XI & $53-108$ & -25.6 & $1039 \pm 35$ & $900-1120$ \\
\hline Sabazan & AA-67531 & charcoal & - & profile & XIII & $108-115$ & -24.6 & $1133 \pm 38$ & $780-990$ \\
\hline Sabazan & AA-67532 & charcoal & - & profile & XIII & $108-115$ & $(-25)$ & $1073 \pm 38$ & $890-1020$ \\
\hline Sabazan & AA-67533 & charcoal & - & profile & XIV & $115-154$ & $(-25)$ & $1172 \pm 36$ & $770-970$ \\
\hline Sabazan & AA-67534 & charcoal & - & profile & XIV & $115-154$ & -24.6 & $1333 \pm 57$ & $600-860$ \\
\hline Sabazan & AA-67535 & charcoal & - & profile & XV & $149-164$ & -24.8 & $1588 \pm 36$ & $400-550$ \\
\hline Sabazan & AA-67536 & charcoal & - & profile & XV & $149-164$ & -25.8 & $1584 \pm 36$ & $410-560$ \\
\hline Sabazan & AA-81054 & charcoal & - & $\operatorname{Tr} 1:$ sq 1 & 2 & $3-13$ & -23.8 & $657 \pm 44$ & $1280-1400$ \\
\hline Sabazan & OS-71407 & charred seed & - & $\operatorname{Tr} 1:$ sq 1 & 4 & $30-34$ & -23.55 & $960 \pm 15$ & $1020-1150$ \\
\hline Sabazan & OS-71408 & charcoal & - & $\operatorname{Tr} 1:$ sq 1 & 5 & $43-53$ & -25.99 & $970 \pm 15$ & $1020-1150$ \\
\hline Sabazan & AA-81056 & charred seed & - & $\operatorname{Tr} 1:$ sq 1 & 6 & $57-67$ & -25.5 & $994 \pm 45$ & $910-1160$ \\
\hline Sabazan & OS-71409 & charcoal & - & $\operatorname{Tr} 1:$ sq 1 & 6 & 73.5 & -24.73 & $925 \pm 15$ & $1040-1160$ \\
\hline Sabazan & OS-71410 & charcoal & - & $\operatorname{Tr} 2:$ sq 1 & 2 & $2-11$ & -26.05 & $>$ modern & modern \\
\hline Sabazan & OS-71462 & charred seed & - & $\operatorname{Tr} 2:$ sq 1 & 3 & $19-29$ & -24.5 & $975 \pm 20$ & $1020-1150$ \\
\hline Sabazan & AA- 81055 & charcoal & - & $\operatorname{Tr} 2:$ sq 1 & $3 \mathrm{~A}$ & $40-50$ & -25.1 & $1158 \pm 45$ & $730-990$ \\
\hline Sabazan & OS-71463 & charcoal & - & $\operatorname{Tr} 2:$ sq 1 & $3 \mathrm{~A}$ & 75.5 & -23.62 & $1140 \pm 15$ & $870-970$ \\
\hline Sabazan & OS-71464 & charred seed & - & $\operatorname{Tr} 2:$ sq 1 & 8 & $89-91$ & -24.03 & $1100 \pm 20$ & $890-990$ \\
\hline Sabazan & OS-71465 & charcoal & - & $\operatorname{Tr} 2:$ sq 1 & 9 & 115 & -24.04 & $1080 \pm 15$ & $900-1010$ \\
\hline Sabazan & OS-71466 & charcoal & - & $\operatorname{Tr} 3:$ sq 1 & 2 & 8-19 & -24.77 & $680 \pm 15$ & $1280-1380$ \\
\hline Sabazan & OS-71467 & charcoal & - & $\operatorname{Tr} 3:$ sq 1 & $3 \mathrm{~A}$ & 84 & -25.67 & $1220 \pm 20$ & $710-880$ \\
\hline \multicolumn{10}{|l|}{ Mustique } \\
\hline Lagoon Bay & $\begin{array}{l}\text { Beta- } \\
286849\end{array}$ & shell & $\begin{array}{l}\text { E. gigas } \\
\text { (juvenile) }\end{array}$ & 2 & 3 & $70-80$ & 0.5 & $1370 \pm 50$ & $910-1160$ \\
\hline \multicolumn{10}{|l|}{ Baliceaux } \\
\hline Banana Bay & $\begin{array}{l}\text { Beta- } \\
286848\end{array}$ & shell & C. pica & S. profile & - & 30 & 2.8 & $970 \pm 50$ & $1310-1460$ \\
\hline Banana Bay & RL-71 & shell & E. gigas & - & - & - & - & $530 \pm 110$ & $1580-1950$ \\
\hline Banana Bay & RL-27 & shell & E. gigas & $\begin{array}{l}10 \mathrm{ft} \text { in } \\
\text { from mid- } \\
\text { den face }\end{array}$ & - & 一 & - & $720 \pm 100$ & $1430-1820$ \\
\hline \multicolumn{10}{|l|}{ Union } \\
\hline $\begin{array}{l}\text { Chatham } \\
\text { Bay }\end{array}$ & RL-70 & shell & E. gigas & - & - & 一 & - & $1470 \pm 110$ & $710-1140$ \\
\hline
\end{tabular}




\section{RESULTS}

The $41{ }^{14} \mathrm{C}$ dates compiled thus far come from 6 sites (Grand Bay, Harvey Vale, Sabazan, Lagoon Bay, Banana Bay, and Chatham Bay) on 4 different islands (Carriacou, Mustique, Baliceaux, and Union) (see Table 1). The majority of the dates are from Carriacou $(n=36 ; 88 \%)$, with $26(63 \%)$ of those coming from the Sabazan site; the remainder $(n=5)$ are from the other 3 islands. Thirteen of the samples are from marine shell, 22 from charcoal, 3 from charred seeds, and 2 from human bone.

All samples were calibrated using CALIB 6.0.1 (www.calib.org) that incorporated the IntCal09 and Marine09 calibration curves (Reimer et al. 2009; see Figure 2 below). Few attempts have been made to determine local marine reservoir effects in the Caribbean. Studies in the Cariaco Basin, Venezuela (Hughen et al. 1996), Jamaica, the Bahamas (Broecker and Olson 1961), and Puerto Rico (Kilbourne et al. 2007) suggest, however, that the $\Delta \mathrm{R}$ may be minimal. The regional average for the Caribbean, including the Florida Keys and locations along the northern South American coast, is now estimated to have a weighted mean $\Delta \mathrm{R}$ of $15 \pm 40$, although this may change as further studies are conducted (also see www.qub.ac.uk/arcpal/marine). Given the dearth of $\Delta \mathrm{R}$ offsets in the Antilles, none of which are local to the Lesser Antilles, we chose not to include them into the calibrations. However, given that the $\Delta \mathrm{R}$ can be significant in many areas of the world and have the potential to alter existing chronologies that rely heavily on marine shell (see Bayliss et al. 2004; Ascough et al. 2005a,b), it is critical that further studies be conducted on this issue.

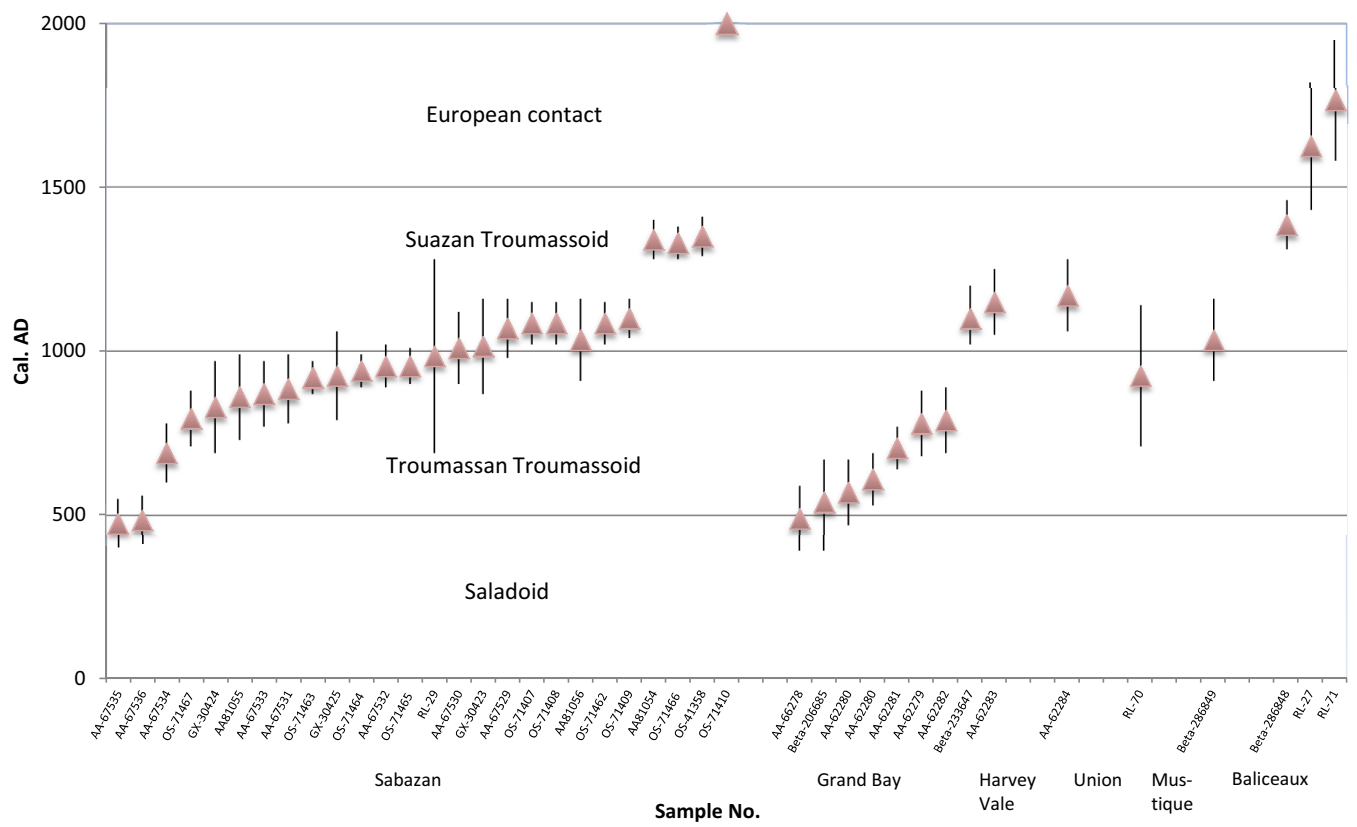

Figure 2 Graph showing range of all calibrated dates $(2 \sigma)$ for sites on Carriacou (Sabazan, Grand Bay, Harvey Vale) and other Grenadine Islands (Union, Mustique, and Baliceaux).

Overall, the earliest date from any of the Grenadine islands comes from the Grand Bay site on Carriacou, which has 2 assays dating back to as early as AD 380/390 (AA-62278, Beta-206685) at $2 \sigma$. That these samples were taken from the lowest portion of cultural layers exposed along the $120-\mathrm{m}$ long coastal profile at both the northern and southern ends suggests this represents the earliest settlement of the site, which occurred during the terminal Saladoid period. While extensive erosion has 
impacted the integrity of the site leading to the annual average loss of $1 \mathrm{~m}$ of coastline per year since at least 1999 (Fitzpatrick et al. 2006), Bullen and Bullen's (1972:13) observation over 40 yr ago that the site was "not occupied during the earlier [i.e. 500/400 BC-AD 1] Saladoid periods" based on pottery types seems to confirm this assessment despite significant loss of anthropogenic deposits. Two other nearly coeval dates from Sabazan dating back to AD 400 (AA-67535, AA-67536) at $2 \sigma$, also from the lowest cultural layer in the coastal profile, indicate that the 2 sites were occupied contemporaneously. Additional dates from 3 excavated trenches at Sabazan located 40-50 m inland from the coast are slightly later in time (about AD 700-800 to 1400), though sterile soil has not yet been reached for 2 of the 3 units. The basal date for the completed unit is AD 1040-1160 (OS$71409)$ at $2 \sigma$. The dates from Grand Bay and Sabazan suggest continuous, long-term occupation of these sites for nearly a millennium.

The earliest available ${ }^{14} \mathrm{C}$ dates from the sites of Banana Bay (Baliceaux) (AD 1310-1460 at $2 \sigma$ [Beta-286848]), Lagoon Bay (Mustique) (AD 910-1160 at $2 \sigma$ [Beta-286849]), and Chatham Bay (Union) (AD 710-1140 at $2 \sigma$ [RL-70]), though few in number, may not be necessarily representative of the earliest occupation of each site, but are nonetheless consistent with an occupation of the Grenadines that took place post-AD 400, which seems to have begun, or intensified, around AD 700. Two additional dates for Baliceaux (RL-27 and RL-71) span a temporal range overlapping or postdating European contact. Three of the 5 dates available for these islands were collected during Bullen and Bullen's (1972) survey through the area, and all but 1 postdating AD 1580 (RL-71) fall within the date ranges of the more recently obtained dates we report here. It should be noted that given the general paucity of good ${ }^{14} \mathrm{C}$ chronologies for most major sites in the Grenadines apart from those on Carriacou, it is difficult to say whether Bullen's dates accurately reflect the sites' true ages (earliest or not). As demonstrated by Fitzpatrick (2006) using a chronometric hygiene approach, sites with only a single date should be viewed cautiously until additional dates are provided to support either local or regional chronologies. The possibility also exists that some dated samples derive from older specimens that can lead to the "old wood" or "old shell" problem (e.g. Rick et al. 2005). In the case of our dates, juveniles of particular marine taxa (usually Strombus (Eustrombus) gigas ${ }^{1}$ and Cittarium pica) in association with terrestrial samples (charcoal or seeds) are typically used for dating to avoid problems with long-lived species and gauge whether there are noticeable differences between or within strata. But, the issue remains that very few sites in the Caribbean have well-established ${ }^{14} \mathrm{C}$ chronologies and single dates of stratigraphic contexts and sites remains problematic. Suffice to say, the dates from Mustique, Baliceaux, and Union all fall within the expected range of settlement for the southern Caribbean on par with Carriacou, though not quite as early. Dates are also consistent with artifact types (e.g. Troumassan and Suazan subseries ceramics) encountered in our recent survey of these sites.

\section{DISCUSSION AND CONCLUSIONS}

Until 2004, only $4{ }^{14} \mathrm{C}$ dates from 3 islands in the Grenadines existed with which to develop a chronology of prehistoric settlement. Our research has increased this 10 -fold, providing a more refined picture of when these islands were settled and how they fit within regional chronologies in the Antilles. The suite of ${ }^{14} \mathrm{C}$ dates now available for the Grenadines suggest that similar to other islands in the southern Lesser Antilles, they were settled relatively late compared to those islands in the north (see Fitzpatrick 2006). When compared to other nearby and much larger islands such as Grenada, Barbados, St. Lucia, and St. Vincent, where several dates go back to the beginning of the 1st millen-

${ }^{1}$ Recent reevaluation of the taxa Strombus gigas suggests that it should be reclassified as Eustrombus gigas. It is reported here as Strombus (Eustrombus) gigas to better follow the current taxonomic division. 
nium AD (see Fitzpatrick 2006) or possibly the late 1st millennium BC, they also appeared to have been settled slightly later in time, though a new suite of dates from Barbados now seem to confirm an Archaic component that goes back to as early as 5000 cal BP.

It remains unclear why the Grenadines appear not to have been permanently settled until a few hundred years after other islands in the southern Lesser Antilles. Given their close geographical proximity, they certainly would have been visible from nearby islands, with the extensive reef systems also a likely attractant for peoples harvesting marine resources (Keegan et al. 2008). If the ${ }^{14} \mathrm{C}$ chronologies hold true, several hypotheses could be proposed for this phenomenon. It is possible that the islands were visited occasionally to gather resources earlier in time, but only after populations began to grow and expand were the Grenadines seen as more viable locales in which to establish permanent villages. Alternatively, a dearth of freshwater sources, or technologies to extract this critical resource (e.g. pot-lined wells), may have inhibited any long-term stays. However, because the majority $(36 / 41 ; 88 \%)$ of dates comes from Carriacou, additional assays from other islands are needed to determine whether this trend can be confirmed.

It is also curious why none of the dates, with the exception of the very small island of Baliceaux, extend beyond cal AD $1400(2 \sigma)$. The later dates for Baliceaux could in fact be explained by the forced settlement of around 5000 Black Caribs to the island by the English in the 1790s. The paucity of contact period dates, however, is a phenomenon observed for various islands in the Caribbean, with some scholars suggesting this may be related to depopulation or site abandonment as a result of the breakdown of exchange networks or increase in conflict (e.g. see Allaire 1991:719; Curet et al. 2001; Hofman and Hoogland 2004).

Regardless, the corpus of ${ }^{14} \mathrm{C}$ dates now available for the Grenadines continue to support a model of initial island colonization in the Caribbean in which peoples from South America initially bypassed the southern islands to permanently settle the northern Antilles first. This model, which we have previously referred to as the "Southward Route Hypothesis" (Fitzpatrick et al. 2010), suggests that oceanographic conditions and/or seafaring technologies played a significant role in structuring the prehistoric colonization of the Antilles from South America during the Ceramic Age (and possibly earlier), favoring initial permanent settlement of Puerto Rico and nearby northern islands to the east first. This hypothesis is supported by computer simulations of seafaring (Callaghan 2001, 2003), the remains of ancient canoes and their presumed capabilities (Callaghan and Schwabe 2001), and radiometric evidence that shows a trend of earlier dates in the northern islands that progressively become younger as one moves south (Haviser 1997; Keegan 2000; Fitzpatrick 2006). Essentially, it is argued that oceanographic and other factors encouraged or influenced peoples to take a more northwesterly trajectory from somewhere along the South American littoral to Puerto Rico and/or islands of the Virgin group and Northern Lesser Antilles first, whereupon they then migrated southward later in time.

Interestingly too, there is a rough correlation in the Grenadines between the earliest date of colonization and current island size in which the larger and southernmost islands appear to have been settled first (Table 2). As a preliminary test, we did a linear regression analysis (SPSS 13.0) to examine whether there was a correlation between the youngest (median point) available date and island size $\left(\mathrm{km}^{2}\right)$. Results indicate that there is a significant positive relationship $(p=0.049, r=0.813)$ between the 2 variables, i.e. the larger the island, the more likely it is have an earlier colonization date. These results are tentative, however. Presently, too few dates exist for most of these islands to reliably test an area-early settlement hypothesis. Additionally, factors including 3-dimensional area (elevation effects on island surface area), fluctuations in sea level during the Late Holocene, and coastal erosion/submersion that may have destroyed sites and/or reduced land size, will need to be considered to examine this question in more detail. 
Table 2 Earliest known dates for islands in the Grenadines representing possible colonization for Grenada and St. Vincent compared to current island size $\left(\mathrm{km}^{2}\right)$ (based on earliest range of $2 \sigma$ calibrations).

\begin{tabular}{lcccc}
\hline Island & $\begin{array}{l}\text { Area } \\
\left(\mathrm{km}^{2}\right)\end{array}$ & $\begin{array}{l}\text { Earliest date } \\
(\text { cal } 2 \sigma)\end{array}$ & $\begin{array}{l}\text { Median date } \\
(\mathrm{cal} 2 \sigma)\end{array}$ & $\begin{array}{l}\mathrm{Nr} \text { of } \\
{ }^{14} \mathrm{C} \text { dates }\end{array}$ \\
\hline Baliceaux & 1.3 & AD 1310 & AD 1385 & 3 \\
Mustique & 5.5 & AD 910 & AD 1035 & 1 \\
Union & 8.4 & AD 710 & AD 925 & 1 \\
Carriacou & 34 & AD 380 & AD 475 & 36 \\
St. Vincent & 344 & AD 1 & AD 330 & 5 \\
Grenada & 310 & 40 BC & AD 100 & 4 \\
\hline
\end{tabular}

While a general paucity of archaeological research in the southern Caribbean has undoubtedly led to numerous lacunae in our understanding of how and when the Caribbean was settled prehistorically, the establishment of a substantial suite of $41{ }^{14} \mathrm{C}$ dates for this region now provides a better framework for examining a host of questions related to how colonization strategies, settlement patterns, and cultural lifeways were structured and how they developed over the course of more than a millennium. Future research dedicated to intensively excavating these and other sites in the Grenadines will allow us to better test various hypotheses on the origins and migrations of Amerindian groups between Caribbean islands and/or South America and determine whether the chronological pattern of settlement to individual islands are real or an artifact of differential survey.

\section{ACKNOWLEDGMENTS}

This research was made possible with funding from a Faculty Research Grant to Fitzpatrick through the Department of Sociology and Anthropology at NC State University (2010) and a National Science Foundation (SBR-0715388) dissertation improvement grant to Giovas and Don Grayson. Logistical support was provided by the Carriacou Historical Society Museum and the Grenada and Carriacou Tourist Offices. We thank all of the students who have participated over the years in fieldwork on Carriacou through NC State University's Study Abroad program. Special thanks go to Ty Kovach and Dianne Wilson of the Mustique Company for arranging logistical support on Mustique and Baliceaux as well as Bryan Adams for graciously providing accommodations during work by Fitzpatrick and Kappers in May 2010. Comments by Richard Callaghan and an anonymous reviewer helped to clarify several issues that improved the paper.

\section{REFERENCES}

Allaire L. 1991. Understanding Suazey. In: Ayubi EN, Haviser JB, editors. Proceedings of the Thirteenth Congress of the International Association for Caribbean Archaeology. Reports of the ArchaeologicalAnthropological Institute of the Netherlands Antilles, No. 9. Curaçao, Netherlands Antilles. p 715-28.

Ascough P, Cook GT, Dugmore AJ. 2005a. Methodological approaches to determining the marine radiocarbon reservoir effect. Progress in Physical Geography 29(4):532-47.

Ascough P, Cook GT, Dugmore AJ, Scott M, Freeman S. $2005 \mathrm{~b}$. Influence of mollusk species on marine $\Delta \mathrm{R}$ determinations. Radiocarbon 47(3):433-40.

Bayliss A, Marshall P, Sidell J. 2004. A puzzling body from the River Thames in London. Radiocarbon 46(1):285-91.
Broecker WS, Olson EA. 1961. Lamont radiocarbon measurements VIII. Radiocarbon 3:176-204.

Bullen RP, Bullen AK. 1972. Archaeological Investigations on St. Vincent and the Grenadines, West Indies. The William L Bryant Foundation, American Studies 8. Orlando: The William Bryant Foundation.

Callaghan R. 2001. Ceramic age seafaring and interaction potential in the Antilles: a computer simulation. Current Anthropology 42:308-13.

Callaghan R. 2003. Comments on the mainland origins of the preceramic cultures of the Greater Antilles. Latin American Antiquity 14:323-38.

Callaghan R. 2007. Prehistoric settlement patterns on St. Vincent, West Indies. Caribbean Journal of Science 43:11-22.

Callaghan R, Schwabe S. 2001. Watercraft of the islands. 
In: l'Association Internationale d'Archéologie de la Caraïbe, editors. Proceedings of the XVIII Congress of the International Association for Caribbean Archaeology, St. Georges, Grenada 1999. Martinique: IACA. p 231-42.

Cooper J. 2010. Pre-Columbian archaeology of Cuba: a study of site distribution patterns and radiocarbon chronologies. In: Fitzpatrick SM, Ross AH, editors. Island Shores, Distant Pasts: Archaeological and Biological Approaches to the Pre-Columbian Settlement of the Caribbean. Gainesville: University Press of Florida. p 81-107.

Curet LA, Newsom LA, Welch D. 2001. Space and time in the civic-ceremonial center of Tibes, Ponce, Puerto Rico. In: Alofs L, Dijkhoff RACF, editors. Proceedings of the Nineteenth Congress of the International Association for Caribbean Archaeology. Publications of the Archaeological Museum Aruba 9. p 142-55.

Devine JD, Sigurdsson H. 1995. Petrology and eruption styles of Kick'em Jenny submarine volcano, Lesser Antilles island arc. Journal of Volcanology and Geothermal Research 69:35-58.

Donovan SK, Pickerill RK, Portell RW, Jackson TA, Harper DAT. 2003. The Miocene palaeobathymetry and palaeoenvironments of Carriacou, the Grenadines, Lesser Antilles. Lethaia 36:255-72.

Drewett P. 1991. Prehistoric Barbados. London: Archetype Publications.

Drewett P, editor. 2000. Prehistoric Settlements in the Caribbean: Fieldwork in Barbados, Tortola, and the Cayman Islands. London: Archetype Publications.

Drewett P. 2007 (Ed.). Above Sweet Waters: Cultural and Natural Change at Port St. Charles, Barbados, c. 1750 $B C-A D$ 1850. London: Archetype Publications.

Fewkes JW. 1914. Relations of aboriginal culture and environment in the Lesser Antilles. Bulletin of the American Geographical Society 46:667-8.

Fitzpatrick SM. 2006. A critical approach to ${ }^{14} \mathrm{C}$ dating in the Caribbean: using chronometric hygiene to evaluate chronological control and prehistoric settlement. Latin American Antiquity 17:389-418.

Fitzpatrick SM, Kaye Q, Kappers M. 2004. A radiocarbon sequence for the Sabazan site, Carriacou, West Indies. Journal of Caribbean Archaeology 5:1-11.

Fitzpatrick SM, Kappers M, Kaye Q. 2006. Coastal erosion and site destruction on Carriacou, West Indies. Journal of Field Archaeology 31:251-62.

Fitzpatrick SM, Kappers M, Kaye Q. 2007. Archaeological research in the Grenadine Islands, West Indies. Journal of Island and Coastal Archaeology 2:251-5.

Fitzpatrick SM, Kappers M, Kaye Q, Giovas C, LeFebvre M, Harris MH, Burnett S, Pavia JA, Marsaglia K, Feathers J. 2009. Precolumbian settlements on Carriacou, West Indies. Journal of Field Archaeology 34: 247-66.

Fitzpatrick SM, Kappers M, Giovas C. 2010. The southward route hypothesis: examining Carriacou's chronological position in Antillean prehistory. In: Fitz- patrick SM, Ross AH, editors. Island Shores, Distant Pasts: Archaeological and Biological Approaches to the Pre-Columbian Settlement of the Caribbean. Gainesville: University Press of Florida. p 163-76.

Giovas CM. 2009. The shell game: analytic problems in archaeological mollusc quantification. Journal of Archaeological Science 36:155-64.

Giovas CM, LeFebvre MJ, Fitzpatrick SM. Forthcoming. New records for prehistoric introduction of neotropical mammals to the West Indies: evidence from Carriacou, Lesser Antilles. Journal of Biogeography.

Haviser JB. 1997. Settlement strategies in the early Ceramic Age. In: Wilson SM, editor. The Indigenous People of the Caribbean. Gainesville: University Press of Florida. p 57-69.

Heath E, MacDonald R, Belkin H, Hawkesworth CJ, Sigurdsoon H. 1998a. Magmagenesis at Soufriere Volcano, St. Vincent, Lesser Antilles Arc. Journal of Petrology 10:1721-64.

Heath E, Turner SP, MacDonald R, Hawkesworth C J, Van Calsteren P. 1998b. Long magma residence times at an island arc volcano (Soufriere, St. Vincent) in the Lesser Antilles: evidence from ${ }^{238} \mathrm{U}-{ }^{230} \mathrm{Th}$ isochron dating. Earth and Planetary Science Letters 160:4963.

Hofman CL, Hoogland MLP. 2004. Social dynamics and change in the northern Lesser Antilles. In: Delpuech A, Hofman CL, editors. Late Ceramic Age Societies in the Eastern Caribbean. Oxford: British Archaeological Reports Series 1273. p 47-58.

Hofman CL, Hoogland MLP. 2009. Interim report on the results of the 2009 (May and June) excavations at the Lavoutte Site (Cas-en-Bas), St. Lucia. The St. Lucia Archaeological and Historical Society. University of Leiden, the Netherlands.

Hughen KA, Overpeck JT, Peterson LC, Anderson RF. 1996. The nature of varved sedimentation in the Cariaco Basin, Venezuela, and its palaeoclimatic significance. In: Kemp AES, editor. Palaeoclimatology and Palaeoceanography from Laminated Sediments. London: Geological Society Special Publication No. 116. p 171-83.

Jackson TA, Scott PW, Donovan SK, Pickerill RK, Portell RW, Harper DAT. 2008. The volcaniclastic turbidites of the Grand Bay Formation, Carriacou, Grenadines, Lesser Antilles. Caribbean Journal of Science 44:116-24.

Keegan WF. 2000. West Indian archaeology 2. Ceramic Age. Journal of Archaeological Research 8:135-67.

Keegan WF, Fitzpatrick SM, Sullivan-Sealy K, LeFebvre M, Sinelli PT. 2008. The role of small islands in marine subsistence strategies: case studies from the Caribbean. Human Ecology 36:635-54.

Kilbourne KH, Quinn TM, Guilderson TP, Webb RS, Taylor FW. 2007. Decadal- to interannual-scale source water variations in the Caribbean Sea recorded by $\mathrm{Pu}-$ erto Rican coral radiocarbon. Climate Dynamics 29: $51-62$. 
Kirby E. 1969. Pre-historic Monuments in Stone. Kingstown: St. Vincent Archaeological and Historical Society.

LeFebvre MJ. 2007. Zooarchaeolgoical analysis of prehistoric vertebrate exploitation at the Grand Bay Site, Carriacou, West Indies. Coral Reefs 26:931-44.

Lindsay JM, Shepherd JB, Wilson D. 2005. Volcanic and scientific activity at Kick'em Jenny submarine volcano 2001-2002: implications for volcanic hazard in the southern Grenadines, Lesser Antilles. Natural Hazards 34:1-24.

Newsom LA, Wing ES. 2004. On Land and Sea: Native American Uses of Biological Resources in the West Indies. Tuscaloosa: University of Alabama Press.

Petersen JB, Hofman CL, Curet AL. 2004. Time and culture: chronology and taxonomy in the eastern Caribbean and the Guianas. In: Delpuech A, Hofman CL, editors. Late Ceramic Age societies in the Eastern Caribbean. Oxford: British Archaeological Reports Series 1273. p 17-32.

Reimer PJ, Baillie MGL, Bard E, Bayliss A, Beck JW, Blackwell PG, Bronk Ramsey C, Buck CE, Burr GS, Edwards RL, Friedrich M, Grootes PM, Guilderson TP, Hajdas I, Heaton TJ, Hogg AG, Hughen KA, Kaiser KF, Kromer B, McCormac FG, Manning SW, Reimer RW, Richards DA, Southon JR, Talamo S, Turney CSM, van der Plicht J, Weyhenmeyer CE. 2009. IntCa109 and Marine09 radiocarbon age calibration curves, 0-50,000 years cal BP. Radiocarbon 51(4): $1111-50$.

Rick T, Vellanoweth R, Erlandson JM. 2005. Radiocarbon dating and the "old shell" problem: direct dating of artifacts and cultural chronologies in coastal and other aquatic regions. Journal of Archaeological Science 32:1641-8.

Rodríguez Ramos R. 2010. Rethinking time in Caribbean archaeology: the Puerto Rico case study. In: Fitz- patrick SM, Ross AH, editors. Island Shores, Distant Pasts: Archaeological and Biological Approaches to the Pre-Columbian Settlement of the Caribbean. Gainesville: University Press of Florida. p 21-53.

Sigurdsson H, Shepherd JB. 1974. Amphibole-bearing basalts from the submarine volcano Kick'em Jenny in the lesser Antilles Island arc. Bulletin of Volcanology 38:891-910.

Speed RC, Smith-Horowitz PL, Perch-Nielsen KS, Saunders JB, Sanfillippo AB. 1993. Southern Lesser Antilles Arc Platform: Pre-Late Miocene Stratigraphy, Structure and Tectonic Evolution. Boulder: Geological Society of America, Special Paper 227.

Stahl PW. 2009. Adventive vertebrates and historical ecology in the pre-Columbian Neotropics. Diversity 1: 151-65.

Sutty L. 1976. Archaeological excavations at Miss Pierre, Union Island, the Grenadines. In: Bullen RP, editor. Proceedings of the Sixth Congress for the Study of Pre-Columbian Cultures of the Lesser Antilles. Poínte à Pitre, Guadeloupe, 6-12 July 1975. Gainesville: Florida State Museum. p 66-75.

Sutty LA. 1991. Paleoecological formations in the Grenadines of Grenada and their relationship to Preceramic and Ceramic settlements: Carriacou. In Ayubi EN, Haviser JB, editors. Proceedings of the Thirteenth International Congress for Caribbean Archaeology. Reports of the Archaeological-Anthropological Institute of the Netherlands Antilles, No. 9, Part 1. Curaçao. p 127-47.

Tupper M, Tan, MK, Tan SK, Radius MJ, Abdullah S. ReefBase: A Global Information System on Coral Reefs [online]. URL: http://www.reefbase.org. Accessed 11 February 2011

Wilson S. 2007. The Archaeology of the Caribbean. Cambridge: Cambridge University Press. 